\title{
The Novel Updates of the Hydrogeological Model of Latvia
}

\author{
Aivars Spalvins ${ }^{1}$, Janis Slangens ${ }^{2}$, Inta Lace ${ }^{3}$, Olgerts Aleksans ${ }^{4}$, \\ Kaspars Krauklis ${ }^{5}$, Viesturs Skibelis ${ }^{6}$, Irina Eglite \\ ${ }^{1-7}$ Riga Technical University
}

\begin{abstract}
In 2010-2012, the hydrogeological model (HM) of Latvia (LAMO) was established by the scientists of Riga Technical University (RTU). LAMO is run by the commercial program Groundwater Vistas (GV). LAMO has generalized the geological and hydrogeological data that were provided for the active groundwater zone by the Latvian Environment, Geology and Meteorology Centre (LEGMC). In 2013-2014, LAMO was notably upgraded and a large amount of real hydrogeological data were added. In 2015, new improvements of LAMO were accomplished. The size of HM plane approximation step was reduced twofold (from 500 meters to 250 meters), the base flows of rivers were calibrated by using the hydrological data of measured river streams, and the permeability maps of $\mathrm{HM}$ aquifers were refined. The present paper describes the essence of the new updates.
\end{abstract}

Keywords - Base flow of rivers, hydrogeological model, hydrographical network, numerical interpolation, Latvia.

\section{INTRODUCTION}

The countries of the European Union (EU) are developing the HM which information is applied for the water resources management that must implement the EU aims defined in the Water Framework Directive [1]. In Latvia, the LEGMC specialists are preparing and updating the water resources management plans for the country.

In 2010-2012, the HM LAMO was established by the scientists of RTU. LAMO simulates the steady state mean hydrogeological situation of Latvia. In Fig. 1, the location of LAMO is shown. LAMO includes 27 geological layers (Fig. 2). The commercial program Groundwater Vistas is used for running of LAMO [2].

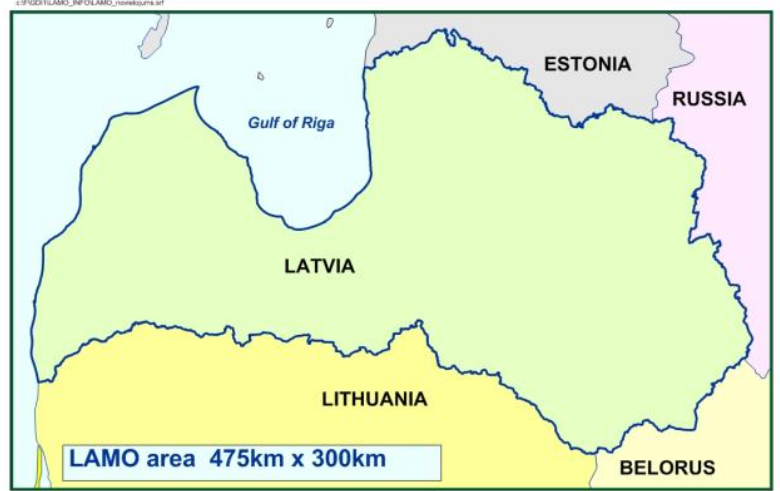

Fig. 1. Location of LAMO.

In [3], the methods applied to create LAMO have been explained, and they are not described in this paper.
In 2013-2014, LAMO was considerably updated [4], [5]. Due to these innovations, four successive versions of LAMO can be marked (Table I).

TABLE I

VERSIONS OF LAMO

\begin{tabular}{|l|c|c|c|c|c|c|c|c|}
\hline $\begin{array}{c}\text { Name of } \\
\text { version }\end{array}$ & $\begin{array}{c}\text { Year of } \\
\text { disposal }\end{array}$ & \multicolumn{2}{|c|}{ Approximation grid } & \multicolumn{3}{|c|}{ Rivers in the model } & Lakes \\
\cline { 3 - 9 } & $\begin{array}{c}\text { Plane } \\
\text { step, } \\
\text { meters }\end{array}$ & $\begin{array}{c}\text { Number } \\
\text { of grid } \\
\text { planes }\end{array}$ & $\begin{array}{c}\text { Number } \\
\text { of cells, } \\
\times 10^{6}\end{array}$ & Number & $\begin{array}{c}\text { Valleys } \\
\text { incised }\end{array}$ & $\begin{array}{c}\text { Flow } \\
\text { data } \\
\text { used }\end{array}$ & Number \\
\hline LAMO1 & 2012 & 500 & 25 & 14.25 & 199 & no & no & 67 \\
\hline LAMO2 & 2013 & 500 & 27 & 15.43 & 199 & yes & no & 67 \\
\hline LAMO3 & 2014 & 500 & 27 & 15.43 & 469 & yes & no & 127 \\
\hline LAMO4 & 2015 & 250 & 27 & 61.56 & 469 & yes & yes & 127 \\
\hline
\end{tabular}

In 2015, the LAMO4 version was developed. In LAMO4, the following innovations were accomplished:

- the HM grid plane approximation step was decreased from 500 meters to 250 meters;

- the river base flow of HM was calibrated by using the data provided by measured river streams (see the Appendix);

- the permeability maps of LAMO4 were considerably improved [6];

- the LAMO4 version was tested as the tool for investigating the mass transport processes for a river [7].

The innovations that have turned LAMO3 into LAMO4 are explained in the paper.

\section{MATHEMATICAL FORMULATIONS}

To describe the new upgrades of LAMO, some mathematics of HM must be considered. By using the 3D finite-difference approximation, the $x y z$ - grid of $\mathrm{HM}$ is built. It consists of $(h \times h \times m)$-sized blocks ( $h$ is the block plane step; $m$ is the variable thickness of a geological layer). For LAMO4, $h=250$ meters.

LAMO provides the 3D distribution of piezometric head $\varphi$ as the numerical solution of the boundary field problem which is approximated in the nodes of the HM grid by the following algebraic expression [4]:

$$
A \varphi=\beta-G \psi, \quad A=A_{x y}+A_{z},
$$

where $A$ is the hydraulic conductivity matrix for the geological environment that contains horizontal $\left(A_{x y}-\right.$ transmissivity $\left.T\right)$ and vertical elements $\left(A_{z}\right.$ - vertical hydraulic conductivity) of the HM grid; $\psi$ and $\beta$ are the boundary head 


\begin{tabular}{|c|c|c|c|}
\hline $\begin{array}{l}\text { No of } \\
\text { HM } \\
\text { plane }\end{array}$ & Name of layer & $\begin{array}{l}\text { Geolo- } \\
\text { gical } \\
\text { code }\end{array}$ & $\begin{array}{l}\text { HM } \\
\text { plane } \\
\text { code } \\
\end{array}$ \\
\hline 1. & Relief & relh & relh \\
\hline 2. & Aeration zone & aer & aer \\
\hline 3. & $\begin{array}{l}\text { Unconfined } \\
\text { Quaternary }\end{array}$ & Q4-3 & Q2 \\
\hline 4. & Upper moraine & gQ3 & gQ2z \\
\hline 5. & $\begin{array}{l}\text { Confined } \\
\text { Quaternary or } \\
\text { Jura }\end{array}$ & $\begin{array}{l}\text { Q1-3 } \\
J\end{array}$ & Q1\# \\
\hline 6. & $\begin{array}{l}\text { Lower moraine } \\
\text { or Triass }\end{array}$ & $\begin{array}{l}\text { gQ1-3 } \\
\text { T }\end{array}$ & gQ1\#Z \\
\hline 7. & $\begin{array}{l}\text { Perma } \\
\text { Karbons } \\
\text { Skerveles } \\
\text { Ketleru }\end{array}$ & $\begin{array}{l}\text { P2 } \\
\text { C1 } \\
\text { D3šk } \\
\text { D3ktl }\end{array}$ & D3ktl\# \\
\hline 8. & Ketleru & D3ktl & D3ktlz \\
\hline 9. & $\begin{array}{l}\text { Zagares } \\
\text { Svetes } \\
\text { Tervetes } \\
\text { Muru }\end{array}$ & $\begin{array}{l}\text { D3žg } \\
\text { D3sv } \\
\text { D3tr } \\
\text { D3mr }\end{array}$ & D3zg\# \\
\hline 10. & Akmenes & D3ak & D3akz \\
\hline 11. & $\begin{array}{l}\text { Akmenes } \\
\text { Kursas } \\
\text { Jonisku }\end{array}$ & $\begin{array}{l}\text { D3ak } \\
\text { D3krs } \\
\text { D3jn }\end{array}$ & D3krs\# \\
\hline 12. & $\begin{array}{l}\text { Elejas } \\
\text { Amulas }\end{array}$ & $\begin{array}{l}\text { D3el } \\
\text { D3aml }\end{array}$ & D3el\#z \\
\hline 13. & $\begin{array}{l}\text { Stipinu } \\
\text { Katlesu } \\
\text { Ogres } \\
\text { Daugavas }\end{array}$ & $\begin{array}{l}\text { D3stp } \\
\text { D3ktl } \\
\text { D3og } \\
\text { D3dg }\end{array}$ & D3dg\# \\
\hline 14. & $\begin{array}{l}\text { Daugavas } \\
\text { Salaspils }\end{array}$ & $\begin{array}{l}\text { D3dg } \\
\text { D3slp }\end{array}$ & D3slp\#z \\
\hline 15. & Plavinu & D3pl & D3pl \\
\hline 16. & $\begin{array}{l}\text { Plavinu } \\
\text { Amatas }\end{array}$ & $\begin{array}{l}\text { D3pl } \\
\text { D3am }\end{array}$ & D3am\#z \\
\hline 17. & Amatas & D3am & D3am \\
\hline 18. & Upper Gauja & D3gj2 & D3gj2z \\
\hline 19. & Upper Gauja & D3gj2 & D3gj2 \\
\hline 20. & Lower Gauja & D3gj1 & D3gj1z \\
\hline 21. & Lower Gauja & D3gj1 & D3gj1 \\
\hline 22. & Burtnieku & D2brt & D2brtz \\
\hline 23. & Burtnieku & D2brt & D2brt \\
\hline 24. & Arikula & D2ar & D2arz \\
\hline 25. & Arikula & D2ar & D2ar \\
\hline 26. & $\begin{array}{l}\text { Narvas } \\
\text { Narvas }\end{array}$ & $\begin{array}{l}\mathrm{D} 2 \mathrm{nr} 2 \\
\mathrm{D} 2 \mathrm{nr} 1\end{array}$ & D2nr\#z \\
\hline 27. & Pernavas & D2prn & $\mathrm{D} 2 \mathrm{pr}$ \\
\hline
\end{tabular}

Fig. 2. Vertical schematization of LAMO. and flow vectors, accordingly; $G$ is the diagonal matrix assembled by the elements linking the nodes where $\varphi$ must be found with the locations where $\psi$ is given.

In $\mathrm{GV}$, the flows for rivers $q_{\text {rivers }}$ and lakes $q_{\text {lakes }}$ are simulated, as follows:

$$
q_{\text {rivers }}=G_{\text {rivers }}\left(\varphi-\psi_{\text {rivers }}\right), \quad q_{\text {lakes }}=G_{\text {lakes }}\left(\varphi-\psi_{\text {lakes }}\right),(2)
$$

where $G_{\text {rivers }}$ and $G_{\text {lakes }}$ are diagonal matrixes (part of $G$ ) that assemble the elements linking the boundary conditions $\psi_{\text {rivers }}$ and $\psi_{\text {lakes }}$ (part of $\psi$ ) for the rivers and lakes with nodes of HM. These links control the interaction of the HM body with the rivers and lakes. In LAMO4, the elements of $G_{\text {rivers }}$ have been adjusted by accounting for the data provided by real measurements of the river streams (see the Appendix).

In $\mathrm{GV}$, the elements $a_{x y}$ of transmissivity $T$ for geological layers are computed, as follows:

$$
a_{x y}=k_{i} m_{i}=T_{i}, m_{i}=z_{i-1}-z_{i}, m_{i}=>0, \quad i=1,2, \ldots, p,
$$

where $z_{i-1}, z_{i}$ are elevations, accordingly, of the top and bottom surfaces of the $i$-th geological layer; $z_{0}$ represents the groundwater surface elevation $\psi_{\text {rel }}$ map; $p$ is the number of $z$-surfaces (for LAMO, $p=28$ ); $m_{i}$ and $k_{i}$ are elements of the digital $m_{i}$ and $k_{i}$-maps of the thickness and permeability of the $i$-th layer, respectively. The $m$-maps include the $m=0$ areas, because most of the LAMO layers are outcropping. The presence of the $m=0$ areas causes problems when the $k$-maps are created by using the formula:

$$
k_{i}=T_{i} / m_{i}
$$

where the $m_{i}$-map acts as the divider; $T_{i}$ is the data obtained from the pumping tests of wells. It is explained in [6] how the problem was solved when the improved $k$-maps for LAMO4 were created.

To accelerate the convergence of iterative solution process of the very large system (1), the $\psi$-type boundary conditions are fixed on the exterior surfaces (top, bottom, sides) of the HM active body. The boundary conditions $\psi_{\text {rivers }}$ and $\psi_{\text {lakes }}$ of (2) also increase the elements of $G$ that ensure faster solution process of (1) [8].

\section{INCREASING DENSITY OF THE LAMO GRID}

The first step of changing the LAMO3 version into the LAMO4 version is increasing density for the HM grid, in order to match the HM body with the fine hydrological network of LAMO3. In LAMO3, some elements of the network were located so close that they were touching. The drawback can be eliminated if the plane approximation step of $\mathrm{HM}$ is reduced from 500 meters to 250 meters. Then density of the HM grid increases fourfold.

In order to investigate how the change in the grid step effects the distribution of all LAMO flows ( $q_{\text {inflow }}, q_{\text {rivers }}, q_{\text {lakes }}$, $\left.q_{\text {wells }}\right)$, the intermediate version LAMO4.1 was created. The elements of $k$-maps and $m$-maps were obtained by linear interpolation. Elements of the $\psi$-type boundary conditions also 
were interpolated In a figurative sense, LAMO4.1 was the "clone" of LAMO3.

In Table II, groundwater flows are given for the LAMO versions. It is obvious that the flows $q_{\text {inflow }}, q_{\text {rivers }}, q_{\text {lakes }}$ of the LAMO4.1 version are smaller than the ones of LAMO3.

TABLE II

GROUNDWATER FLOWS, THOUS. M³/DAY, FOR LAMO VERSIONS

\begin{tabular}{|l|c|c|c|c|c|}
\hline $\begin{array}{l}\text { Name of } \\
\text { version }\end{array}$ & $q_{\text {inflow }}$ & $q_{\text {rivers }}$ & $q_{\text {lakes }}$ & $q_{\text {boundary }}$ & $q_{\text {wells }}$ \\
\hline LAMO2 & 7199 & -5680 & -428 & -936 & -155 \\
\hline LAMO3 & 10763 & -9436 & -599 & -499 & -155 \\
\hline LAMO4.1 & 10349 & -9104 & -541 & -549 & -155 \\
\hline LAMO4.2 & 14221 & -12386 & -825 & -855 & -155 \\
\hline
\end{tabular}

LAMO4.1 is the "clone" of LAMO3;

LAMO4.2 is calibrated by adjusting $q_{\text {rivers }}$.

TABLE III

FLOWS OF RIVERS AND LAKES IN LAMO3 AND LAMO4.1

\begin{tabular}{|l|l|l|l|l|l|l|}
\hline \multirow{2}{*}{$\begin{array}{l}\text { Name of } \\
\text { version }\end{array}$} & \multicolumn{2}{l|}{$\begin{array}{l}\text { Groundwater } \\
\text { flow, thous. } \\
\mathrm{m}^{3} / \mathrm{day}\end{array}$} & \multicolumn{2}{l|}{$\begin{array}{l}\text { Number of nodes } \\
\text { joined with rivers } \\
\text { and lakes }\end{array}$} & \multicolumn{2}{l|}{$\begin{array}{l}\text { Area joined with } \\
\text { rivers and lakes, } \\
\mathrm{km}^{2}\end{array}$} \\
\cline { 2 - 7 } & $q_{\text {rivers }}$ & $q_{\text {lakes }}$ & $N_{\text {rivers }}$ & $N_{\text {lakes }}$ & $L_{\text {rivers }}$ & $L_{\text {lakes }}$ \\
\hline LAMO3 & 9436 & 599 & 42137 & 6093 & 10534 & 1523 \\
\hline LAMO4.1 & 9104 & 541 & 89683 & 19321 & 5605 & 1207 \\
\hline
\end{tabular}

In Table III, information is presented about the areas which join the HM with rivers and lakes. These data explain why the flows $q_{\text {rivers }}$ and $q_{\text {lakes }}$ in LAMO4.1 are smaller than in LAMO3. The areas $L_{\text {river }}$ and $L_{\text {lakes }}$ that have links with rivers and lakes can be computed, as follows:

$$
L_{\text {river }}=N_{\text {river }} h^{2}, \quad L_{\text {lakes }}=N_{\text {lakes }} h^{2}
$$

where $N_{\text {river }}$ and $N_{\text {lakes }}$ are the number of rivers and lakes, respectively. By using (6), data of Table III were obtained if $h=0.5 \mathrm{~km}$ and $0.25 \mathrm{~km}$ for LAMO3 and LAMO4.1, respectively. For LAMO4.1, $N_{\text {river }}=89688$ is almost two times larger than for LAMO3 (42 137). The area $L_{\text {river }}=5605$ $\mathrm{km}^{2}$ for LAMO4.1 is almost two times smaller than that for LAMO3 $\left(10534 \mathrm{~km}^{2}\right)$. For this reason, $q_{\text {rivers }}$ is smaller for LAMO4.1. However, the sum of links for $G_{\text {rivers }}$ is almost equal for both versions.

For LAMO4.1, the $L_{\text {lakes }}$ area is smaller than that for LAMO3, because the number $N_{\text {lakes }}$ is smaller for LAMO4.1. This is caused by the finer approximation of the lake areas, when $h=250$ meters. For this reason, $q_{\text {lakes }}$ is smaller for LAMO4.1. The decrease in the flow $q_{\text {inflow }}$ for LAMO4.1 is caused by the the smaller flows $q_{\text {rivers }}$ and $q_{\text {lakes }}$.

\section{Calibration of HM by Accounting for Measured RIVER STREAMS}

The second step of creating of LAMO4 is the change of the LAMO4.1 version into LAMO4.2 by accounting for the data provided of measured river streams. It is explained in the Appendix how these data have been used for obtaining the targets for calibration of 69 primary drainage basins of LAMO. The links $G_{\text {river }}$ of (2) were adjusted to match the simulated $q_{\text {river }}$ with the target flow of the basin under consideration. It follows from Table IA in the Appendix that the rather close match has been achieved for each primary basin and also for the whole territory of Latvia.

In Tables IV-VIII, the simulated groundwater flows for Latvia and for the united river basins of Gauja, Daugava, Lielupe, and Venta are represented, accordingly. Each row of those Tables contains the local groundwater flow balance that is obtained by the mass balance tool of $\mathrm{GV}$.

For an aquifer, $\mathrm{GV}$ computes the flows $q_{\text {topin }}, q_{\text {topout }}, q_{\text {botin }}$, and $q_{\text {botout. }}$ The sum of these flows is the inflow $q_{\text {inflow: }}$ :

$$
q_{\text {inflow }}=q_{\text {topin }}+q_{\text {topout }}+q_{\text {botin }}+q_{\text {botout }} .
$$

The flow $q_{\text {inflow }}$ exists only for the $m>0$ area of a layer. The GV system also finds the flows $q_{\text {river }}, q_{\text {lakes }}, q_{\text {border, }}$ and $q_{\text {wells }}$, accordingly, for rivers, lakes, external boundaries, and exploitation wells.

The sum of these flows must be in balance with $q_{\text {inflow: }}$ :

$$
q_{\text {inflow }}+q_{\text {river }}+q_{\text {lakes }}+q_{\text {border }}+q_{\text {wells }}=0 \text {. }
$$

The graphical scheme for the expressions (7) and (8) is given in Figs 3a and 3b, correspondingly. There the "Module" represents any part of the geological environment which flow balance is under consideration.

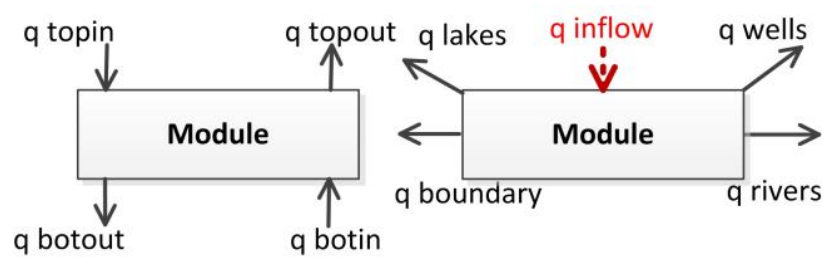

a) sources of inflow

b) local balance

Fig. 3. The scheme for explanation of the flow balance.
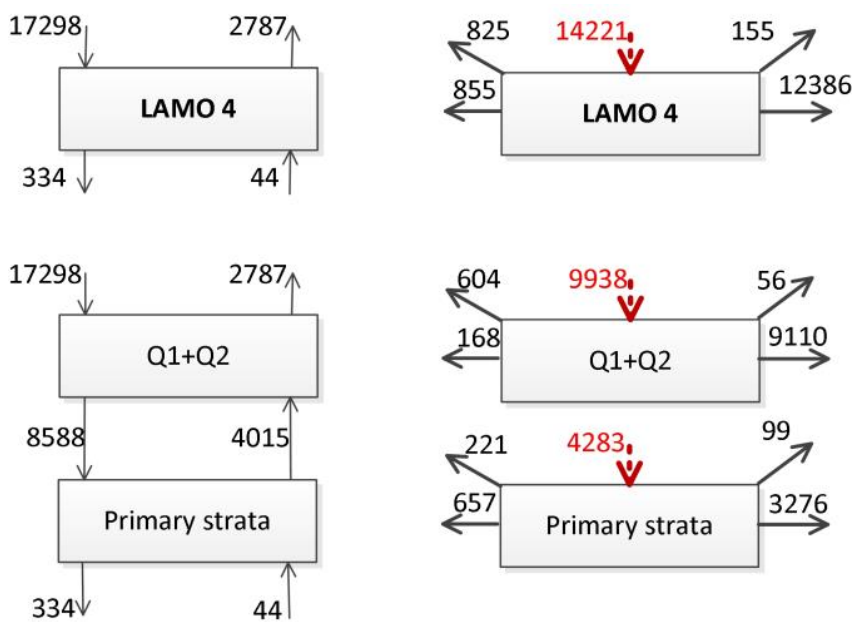

Fig. 4. Mass balances, thous. $\mathrm{m}^{3} /$ day, for LAMO4, Latvia. 
In Tables IV-VIII, the local flow balance is given for any aquifer, for whole HM, for the Quaternary, and for Primary strata systems.

In Fig. 4, the last three rows of Table IV are exposed.

In the Tables IV-VIII, the row for the Q2 aquifer does not provide the full information about the flow balance on the top of HM. It follows from this balance that some part of the infiltration flow $q_{\text {inf }}$ returns for the ground surface as the runoff flow $q_{\text {runoff. }}$ This fact is explained in Table IX, where the balance on the top of Q2 aquifer is shown for the united river basins and for Latvia. The ratio $q_{\text {runoff. }} / q_{\text {inf. shows }}$ the relative part of the infiltration that turns into the surface runoff flow. It takes place at areas where the ascending groundwater flow reaches the land surface, usually, at lowland areas.

The data regarding flow balances for Latvia and its four united river basins will be analyzed in order to obtain deeper understanding of the groundwater processes of the country. The computer-based inventory for river base flows $q_{\text {river }}$ will be developed in order to account for sources that support them.

TABLE IV

LATVIA GROUNDWATER FLOWS, THOUS. M³/DAY

\begin{tabular}{|l|c|c|c|c|c|}
\hline $\begin{array}{l}\text { Aquifer } \\
\text { code }\end{array}$ & $q_{\text {inflow }}$ & $q_{\text {rivers }}$ & $q_{\text {lakes }}$ & $q_{\text {border }}$ & $q_{\text {wells }}$ \\
\hline Q2 & 9723 & -8920 & -603 & -144 & -56 \\
\hline Q1\# & 215 & -190 & -1 & -24 & 0 \\
\hline D3ktl\# & 187 & -199 & -16 & 29 & -1 \\
\hline D3zg\# & 68 & -63 & -3 & 2 & -4 \\
\hline D3krs\# & 101 & -74 & 0 & -23 & -4 \\
\hline D3dg\# & 976 & -762 & -176 & -34 & -4 \\
\hline D3pl & 627 & -463 & -12 & -144 & -8 \\
\hline D3am & 210 & -202 & 0 & -7 & -1 \\
\hline D3gj2 & 597 & -484 & 0 & -88 & -25 \\
\hline D3gj1 & 442 & -282 & -6 & -129 & -25 \\
\hline D2brt & 916 & -747 & -8 & -148 & -13 \\
\hline D2ar & 153 & 0 & 0 & -145 & -14 \\
\hline Model & 14221 & -12386 & -825 & -855 & -155 \\
\hline Q1+Q2 & 9938 & -9110 & -604 & -168 & -56 \\
\hline Primary & 4283 & -3276 & -221 & -687 & -99 \\
\hline aquifers & & & & & \\
\hline
\end{tabular}

TABLE V

THE GAUJA RIVER BASIN GROUNDWATER FlOWS, THOUS. M³/DAY

\begin{tabular}{|l|c|c|c|c|c|}
\hline $\begin{array}{l}\text { Aquifer } \\
\text { code }\end{array}$ & $q_{\text {inflow }}$ & $q_{\text {rivers }}$ & $q_{\text {lakes }}$ & $q_{\text {border }}$ & $q_{\text {wells }}$ \\
\hline Q2 & 1925 & -1806 & -80 & -31 & -8 \\
\hline Q1\# & 52 & -47 & 0 & -5 & 0 \\
\hline D3dg\# & 136 & -110 & 0 & -26 & 0 \\
\hline D3pl & 120 & -104 & 0 & -16 & 0 \\
\hline D3am & 131 & -131 & 0 & 0 & 0 \\
\hline D3gj2 & 397 & -417 & 0 & 20 & \\
\hline D3gj1 & 219 & -214 & -6 & 2 & -1 \\
\hline D2brt & 681 & -642 & 0 & -34 & -5 \\
\hline D2ar & 30 & 0 & 0 & -2 & -5 \\
\hline Model & 3691 & -3471 & -86 & -116 & -18 \\
\hline Q1+Q2 & 1977 & -1853 & -80 & -37 & -7 \\
\hline $\begin{array}{l}\text { Primary } \\
\text { aquifers }\end{array}$ & 1714 & -1618 & -6 & -79 & -11 \\
\hline
\end{tabular}

TABLE VI

THE DAUgava River BAsin GROUNDWATER Flows, THOUS. M³/DAY

\begin{tabular}{|l|c|c|c|c|c|}
\hline $\begin{array}{l}\text { Aquifer } \\
\text { code }\end{array}$ & $q_{\text {inflow }}$ & $q_{\text {rivers }}$ & $q_{\text {lakes }}$ & $q_{\text {border }}$ & $q_{\text {wells }}$ \\
\hline Q2 & 4839 & -4448 & -368 & 26 & -49 \\
\hline Q1\# & 83 & -90 & -1 & 8 & 0 \\
\hline D3dg\# & 504 & -317 & -172 & -11 & -4 \\
\hline D3pl & 431 & -302 & -12 & -110 & -7 \\
\hline D3am & 7 & -2 & 0 & -5 & 0 \\
\hline D3gj2 & 113 & -12 & 0 & -80 & -21 \\
\hline D3gj1 & 108 & 0 & 0 & -101 & -7 \\
\hline D2brt & 84 & 0 & 0 & -82 & -2 \\
\hline D2ar & 78 & 0 & 0 & -77 & -1 \\
\hline Model & 6247 & -5171 & -553 & -432 & -91 \\
\hline Q1+Q2 & 4922 & -4538 & -369 & -34 & -49 \\
\hline $\begin{array}{l}\text { Primary } \\
\text { aquifers }\end{array}$ & 1325 & -633 & -184 & -466 & -42 \\
\hline
\end{tabular}

TABLE VII

THE LIELUPE RIVER BASIN GROUNDWATER FLOWS, THOUS. M³/DAY

\begin{tabular}{|l|c|c|c|c|c|}
\hline $\begin{array}{l}\text { Aquifer } \\
\text { code }\end{array}$ & $q_{\text {inflow }}$ & $q_{\text {rivers }}$ & $q_{\text {lakes }}$ & $q_{\text {border }}$ & $q_{\text {wells }}$ \\
\hline Q2 & 969 & -947 & -29 & 7 & 0 \\
\hline Q1\# & 8 & -8 & 0 & 0 & 0 \\
\hline D3ktl\# & 0 & 0 & 0 & 0 & 0 \\
\hline D3zg\# & 13 & -16 & 0 & 3 & 0 \\
\hline D3krs\# & 15 & -17 & 0 & 3 & -1 \\
\hline D3dg\# & 105 & -125 & -1 & 21 & 0 \\
\hline D3pl & 8 & -1 & 0 & -7 & 0 \\
\hline D3am & -1 & 0 & 0 & 2 & -1 \\
\hline D3gj2 & -8 & 0 & 0 & 11 & -3 \\
\hline D3gj1 & -1 & 0 & 0 & 15 & -14 \\
\hline D2brt & -7 & 0 & 0 & 8 & -1 \\
\hline D2ar & -1 & 0 & 0 & 1 & 0 \\
\hline Model & 1100 & -1114 & -30 & 64 & -20 \\
\hline Q1+Q2 & 977 & -955 & -29 & 7 & 0 \\
\hline Primary & 123 & -159 & -1 & 57 & -20 \\
\hline aquifers & & & & & \\
\hline
\end{tabular}

TABLE VIII

THE VENTA RiVER BASIN GROUNDWATER FLOWS, THOUS. M³/DAY

\begin{tabular}{|l|c|c|c|c|c|}
\hline $\begin{array}{l}\text { Aquifer } \\
\text { code }\end{array}$ & $q_{\text {inflow }}$ & $q$ rivers & $q$ lakes & $q$ border & $q_{\text {wells }}$ \\
\hline Q2 & 1990 & -1719 & -126 & -145 & 0 \\
\hline Q1\# & 72 & -45 & 0 & -27 & 0 \\
\hline D3ktl\# & 187 & -199 & -16 & 29 & -1 \\
\hline D3zg\# & 55 & -47 & -3 & 1 & -4 \\
\hline D3krs\# & 86 & -57 & 0 & -26 & -3 \\
\hline D3dg\# & 231 & -210 & -3 & -18 & 0 \\
\hline D3pl & 68 & -56 & 0 & -12 & 0 \\
\hline D3am & 73 & -69 & 0 & -4 & 0 \\
\hline D3gj2 & 95 & -55 & 0 & -39 & -1 \\
\hline D3gj1 & 116 & -68 & 0 & -45 & -3 \\
\hline D2brt & 158 & -105 & -8 & -40 & -5 \\
\hline D2ar & 52 & 0 & 0 & -43 & -9 \\
\hline Model & 3183 & -2630 & -156 & -371 & -26 \\
\hline Q1+Q2 & 2062 & -1764 & -126 & -172 & 0 \\
\hline $\begin{array}{l}\text { Primary } \\
\text { aquifers }\end{array}$ & 1121 & -866 & -30 & -199 & -26 \\
\hline
\end{tabular}


TABLE IX

THE SURFACE RUNOFF FLOW $q_{\text {runof, }}$ THOUS. ${ }^{3} /$ DAY, ORIGINATED FROM INFILTRATION $q_{\text {inf }}$

\begin{tabular}{|l|c|c|c|c|}
\hline $\begin{array}{l}\text { Name of } \\
\text { basin }\end{array}$ & $\begin{array}{l}q_{\text {topin }} \\
\left(q_{\text {inf }}\right)\end{array}$ & $\begin{array}{l}q_{\text {topout }} \\
\left(q_{\text {runoff }}\right)\end{array}$ & $\begin{array}{l}q_{\text {toprez }} \\
(2+3)\end{array}$ & $\begin{array}{l}q_{\text {runoff }} / q_{\text {inf }} \\
(3 / 2)\end{array}$ \\
\hline 1 & 2 & 3 & 4 & 5 \\
\hline Gauja & 4265 & -529 & 3736 & -0.124 \\
\hline Daugava & 7726 & -1251 & 6475 & -0.162 \\
\hline Lielupe & 1334 & -246 & 1088 & -0.184 \\
\hline Venta & 3973 & -761 & 3212 & -0.192 \\
\hline Latvia & 17298 & -2787 & 14511 & -0.161 \\
\hline
\end{tabular}

\section{IMPROVING OF PERMEABILITY MAPS FOR PRIMARY AQUIFERS}

For the LAMO3 version, its $k$-maps were improved by using the data provided by the pumping tests of wells [5]. However, the following problems of using the formula (4) were not solved satisfactorily:

- jumpwise changes in $k$ were not eliminated at locations of incised river valleys;

- in the $m \rightarrow 0$ areas, extreme values of $k$ were not suppressed;

- data of well pumping tests were not validated.

For LAMO4, these drawbacks have been eliminated [7]:

- the jumpwise changes have been excluded, because the $m_{0}$-maps without incisions were used for the LAMO4 case. Such maps are being used as the starting position for all necessary changes in the HM geometry;

- to suppress the extreme $k$ values for the $m \rightarrow 0$ zone, the following correction matrix $C$ was used:

$$
1>\mathrm{C}=m_{0} /\left(0.75 m_{\text {mean }}\right),
$$

where the factor 0.75 was chosen empirically; $m_{\text {mean }}$ is the mean thickness of an aquifer in its $m>0$ area. The corrected $k_{\text {cor }}$ and $T$ for $\mathrm{GV}$ were obtained, as follows:

$$
\gamma_{\mathrm{cor}}=G \gamma, \quad k_{\mathrm{cor}}=137 \gamma_{\mathrm{cor}} / m_{0}, \quad T=k_{\text {cor }} m,
$$

where $\gamma$, liter/sec $\mathrm{km}^{2}$, is the well's specific capacity which is obtained from a pumping test; $m$ is the real $m$-map of LAMO4 where incisions of river valleys exist. The specific capacity $\gamma$ data of (8) were taken only from verified wells. The verification was done by a special software tool that was developed for this task [6].

In Table $\mathrm{X}$, the summary on the $k$-maps of LAMO2, LAMO3, and LAMO4 versions is given [6]. For each HM version, $k_{\text {mean }}$ and $k_{\text {max }} / k_{\text {mean }}$ are presented. For the LAMO2 version, $k_{\text {max }} / k_{\text {mean }}=1.0$, because constant values of $k$ were used for all aquifers. For the LAMO3 and LAMO4 versions, the ratio $k_{\text {max }} / k_{\text {mean }}$ is variable. For LAMO4, the ratio $k_{\text {max }} / k_{\text {mean }}$ is larger than for the LAMO3 version, because the values $q_{\min }=0.2$ and 0.3 were used for bounding of the initial data of LAMO3 and LAMO4, correspondingly.
TABLE X

SUMMARY ON THE LAMO2, LAMO3 AND LAMO4 $K$-MAPS OF THE PRIMARY AQUIFERS

\begin{tabular}{|c|c|c|c|c|c|c|}
\hline \multirow{2}{*}{$\begin{array}{c}\text { Aquifer } \\
\text { code }\end{array}$} & \multicolumn{2}{|c|}{ LAMO2 } & \multicolumn{2}{c|}{ LAMO3 } & \multicolumn{2}{c|}{ LAMO4 } \\
\cline { 2 - 7 } & $\begin{array}{c}k_{\text {mean }}, \\
\text { meter/day }\end{array}$ & $k_{\text {max }} / k_{\text {mean }}$ & $\begin{array}{c}k_{\text {mean }}, \\
\text { meter/day }\end{array}$ & $k_{\text {max }} / k_{\text {mean }}$ & $\begin{array}{c}k_{\text {mean }} \\
\text { meter/day }\end{array}$ & $k_{\text {max }} / k_{\text {mean }}$ \\
\hline D3ktl\# & 3.0 & 1.0 & 2.12 & 9.0 & 1.77 & 12.10 \\
\hline D3zg\# & 3.0 & 1.0 & 3.64 & 5.33 & 3.38 & 15.75 \\
\hline D3krs\# & 2.0 & 1.0 & 5.95 & 4.35 & 6.33 & 9.89 \\
\hline D3dg\# & 10.0 & 1.0 & 5.58 & 14.38 & 9.40 & 16.06 \\
\hline D3pl & 10.0 & 1.0 & 6.11 & 8.51 & 8.60 & 19.65 \\
\hline D3am & 10.0 & 1.0 & 4.69 & 5.67 & 4.64 & 11.25 \\
\hline D3gj2 & 10.0 & 1.0 & 5.58 & 4.55 & 5.11 & 20.05 \\
\hline D3gj1 & 14.0 & 1.0 & 5.24 & 6.25 & 4.84 & 16.00 \\
\hline D2brt & 5.0 & 1.0 & 1.91 & 5.83 & 3.19 & 13.75 \\
\hline D2ar & 5.0 & 1.0 & 2.13 & 6.15 & 2.91 & 17.69 \\
\hline
\end{tabular}

It is possible to improve the $k$-maps of LAMO4, if the data of screens positions of wells will be accounted for [6].

\section{APPLIANCE OF LAMO FOR GROUNDWATER PARTICLE TRACKING}

In the GV system, the MODFLOW program [9] is used for running LAMO. This program is joined with the MODPATH program [10] that is applied for tracking of groundwater particles. MODTATH can provide useful results only if MODFLOW carries reliable HM, such as LAMO4. It is described in [11] that the appliance of MODPATH with the HM for Lithuania eastern part provided very impressive results on modeling isotope geochemistry.

MODPATH is often used for finding borders of sanitary protection zones of well fields. Then the migration time for water particles does not exceed 25 years.

In the paper [7], the case of the Iecava river is investigated by using MODPATH for finding sources of the river base flow. As expected, the inflow through the HM top surface (caused by precipitation) forms the river base flow. A small part of the base flow is caused by the ascending flow from the HM bottom surface. However, if the particle tracking time was not limited, it turned out that some amount of groundwater comes from the areas located very far from the drainage basin of the river. Also, it was not expected that even within the drainage basin, many particle traces had very complex 3D shapes. This unforeseen fact will be investigated for other rivers of the country.

\section{CONCLUSION}

In 2015, the new upgrades of the hydrogeological model of Latvia LAMO4 were accomplished. The plane approximation step of the HM grid was decreased from 500 meters to 250 meters. The river flows of LAMO4 account for real measurements of the river streams of Latvia. The LAMO4 version will be applied for updating the information that is necessary for water management planning, as the base for building detailed local models, and for investigation of complex geochemical processes. 


\section{ACKNOWLEDGMENT}

In 2010-2012, the hydrogeological model of Latvia LAMO1 was developed within the framework of the Riga Technical University project that was co-financed by the European Regional Development Fund. The current upgrades of LAMO3 and LAMO4 are supported by the Latvian State Research program EVIDEnT.

\section{APPENDIX}

\section{ESTIMATION OF THE LATVIA'S MEAN RIVER BASE FLOW THAT SHOULD BE SIMULATED BY LAMO4}

\section{A. General Hydrological Relationships}

For the steady state mean hydrological conditions of Latvia, the general relationship holds:

$$
q_{\mathrm{prec}}=q_{\mathrm{inf}}+q_{\mathrm{run}}+q_{\mathrm{evap}}
$$

where $q_{\text {prec }}, q_{\text {inf }}, q_{\text {run }}$, and $q_{\text {evap }}$ are the mean flows of precipitation, infiltration, surface runoff, and evaporation, respectively.

The LAMO system simulates the spatial distribution of the infiltration $q_{\text {inf }}$ that contains the following parts [4]:

$$
q_{\text {inflow }}=q_{\text {rivers }}+q_{\text {lakes }}+q_{\text {wells }}+q_{\text {boundary }}
$$

where $q_{\text {rivers }}, q_{\text {lakes }}, q_{\text {wells }}$, and $q_{\text {boundary }}$ are the mean flows of rivers (base flow), lakes, discharge wells, and the flow passing through the borderline of Latvia, accordingly.

The full flow of rivers $q_{\text {friv }}$, which can be directly measured, contains two parts:

The ratio:

$$
q_{\text {friv }}=q_{\text {rivers }}+q_{\text {run }}
$$

$$
q_{\text {rivers }} / q_{\text {friv }}=q_{\text {rivers }} /\left(q_{\text {rivers }}+q_{\text {run }}\right)
$$

displays the relative part of groundwater (base flow of a river) into the full flow $q_{\text {friv. }}$ The measured flow $q_{\text {friv }}$ in time is the river stream hydrograph.

To obtain $q_{\text {rivers }}$ for a drainage basin, the hydrograph must be separated into its groundwater and surface runoff parts.

When the river base flow $q_{\text {rivers }}$ is found, the groundwater inflow, thous. $\mathrm{m}^{3} / \mathrm{day}$, into the river or its segment can be described by the relationship:

$$
M_{\text {rivers }}=q_{\text {rivers }} /\left(86.4 L_{\text {rivers }}\right),
$$

where $M_{\text {rivers }}$ (liter/sec $\mathrm{km}^{2}$ ) and $L_{\text {rivers }}$ (thous. $\mathrm{km}^{2}$ ) are the river drainage module and the area of the drainage basin, respectively.

In books [12] and [13], the data of $M_{\text {rivers }}$ are available for the river stream monitoring stations of Latvia. The isoline maps of $M_{\text {rivers }}$ are also presented for the land area of the country.

It can be deduced from [12] that the general hydrological parameters of Latvia have the following mean values $(\mathrm{mm} /$ year $): q_{\text {prec }}=710 ; q_{\text {inf }}=80 ; q_{\text {run }}=185 ; q_{\text {evap }}=445$. For LAMO3, $q_{\text {rivers }} \sim 0.87 q_{\text {inf. }}$ Therefore:

$q_{\text {rivers }} \sim 70 \mathrm{~mm} /$ year $\sim 124000$ thous. $\mathrm{m}^{3} /$ day; $q_{\text {rivers }} / q_{\text {friv }}=70 /(70+185)=0.275$;

$$
M_{\text {rivers }}=12400 /(86.4 \times 64.5)=2.22 \text { liter } / \mathrm{sec} \mathrm{km}^{2} \text {. }
$$

The $q_{\text {rivers }} \sim 124000$ thous. $\mathrm{m}^{3} /$ day is the mean value for the land territory of Latvia. To calibrate LAMO by accounting for the results of measured river stream flows, the distributions of $q_{\text {rivers }}$ and $M_{\text {rivers }}$ have to be found for local drainage basins.

It is explained in [14] and [15] how from the hydrograph of a river, the base flow $q_{\text {rivers }}$ can be sorted out. Estimates of $q_{\text {rivers }}$ for LAMO4 were obtained by using the data of books [12] and [13].

\section{B. Estimation of the River Base Flows for Local Drainage Basins}

The land territory of Latvia was divided into 69 primary local drainage basins (Fig. 1a). Each basin is enveloped by its polygon. By using the polygon, in $\mathrm{GV}$ the full mass balance (2a) for the drainage basin and for its Quaternary aquifer Q2 can be obtained. The difference of these balances gives the balance for the primary aquifers. By using these data, calibration of $q_{\text {rivers }}$ for the basin can be done by comparing the projected river flows as targets with the existing ones. The existing flows must be changed in order to match the targets. In most of the cases, the result can be achieved by adjusting the links of rivers with the drainage basin.

Each primary drainage basin is marked by its number that contains four positions. The positions have the following meaning:

- the first is the number of the four united river basins of Latvia: 1 - Gauja; 2 - Daugava; 3 - Lielupe; 4 - Venta;

- the second is the number of subbasins of the united ones; the basins have the following number of subbasins: Gauja - 3; Daugava - 2; Lielupe - none; Venta - 4;

- the third denotes the numbers of segments of subbasins of the four larger rivers which have the following number of segments: Gauja - 7; Daugava, Lielupe, Venta -4 . The number of segments and their location depends on the set of river stream monitoring posts on a river;

- the fourth is the number of the primary drainage basin within a segment.

In Fig. 1a, Fig. 2a, Fig. 3a, and Fig. 4a, accordingly, the 69 primary drainage basins, 34 segments of basins, 10 subbasins, and 4 united basins are shown.

To estimate the river base flow for the primary drainage basins, the map of isolines for the drainage module $M$ [12] was projected on the map of Fig. 1a (see Fig. 5a). By taking into account the data carried by Fig. 5a and the information provided by the book [13], the river base flows for each of the 69 primary drainage basins were estimated (Table IA). By using data of Table IA, the estimated river base flows for 4 united basins and 10 subbasins were obtained (Table IIA). Table IIIA contains data for segments of the four largest rivers of Latvia.

The mean estimated river base flow 12423 thous. $\mathrm{m}^{3} /$ day for Latvia (Table IIa) is only slightly larger than 12400 thous. $\mathrm{m}^{3} /$ day that was obtained from the general hydrological parameters of Latvia. 


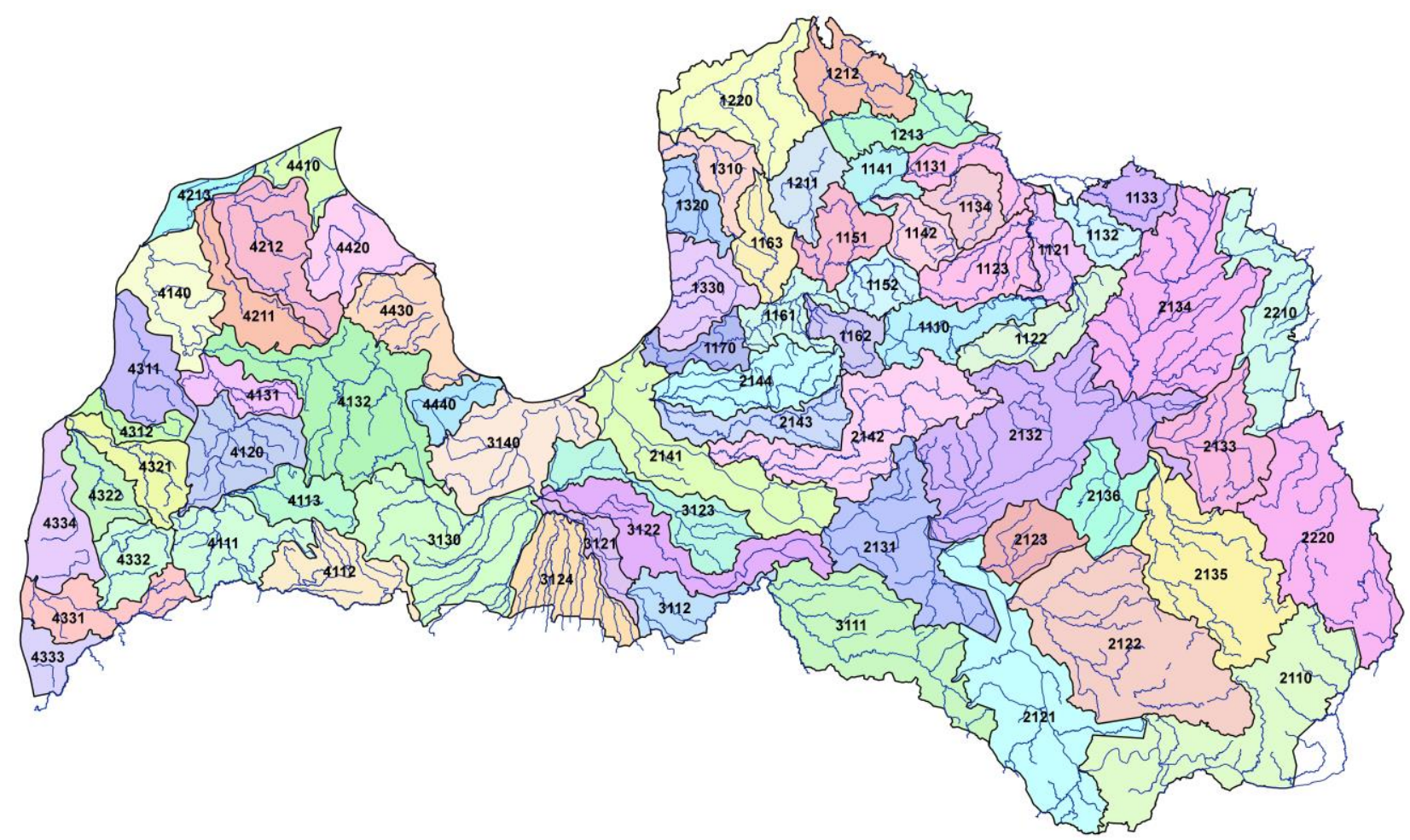

Fig. 1a. 69 primary drainage basins used for calibration of river flows.

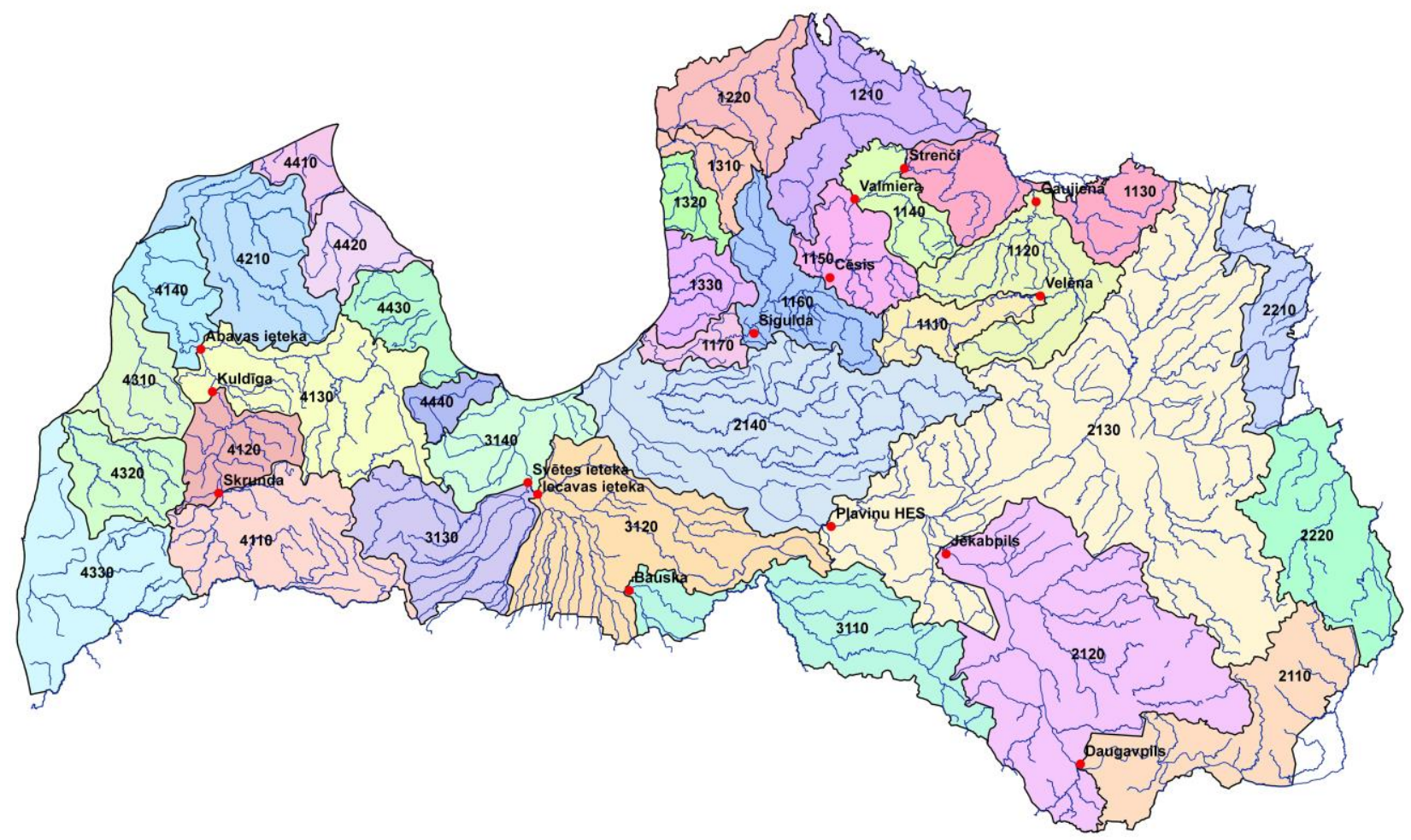

Fig. 2a. 34 segments of monitored river basins. 


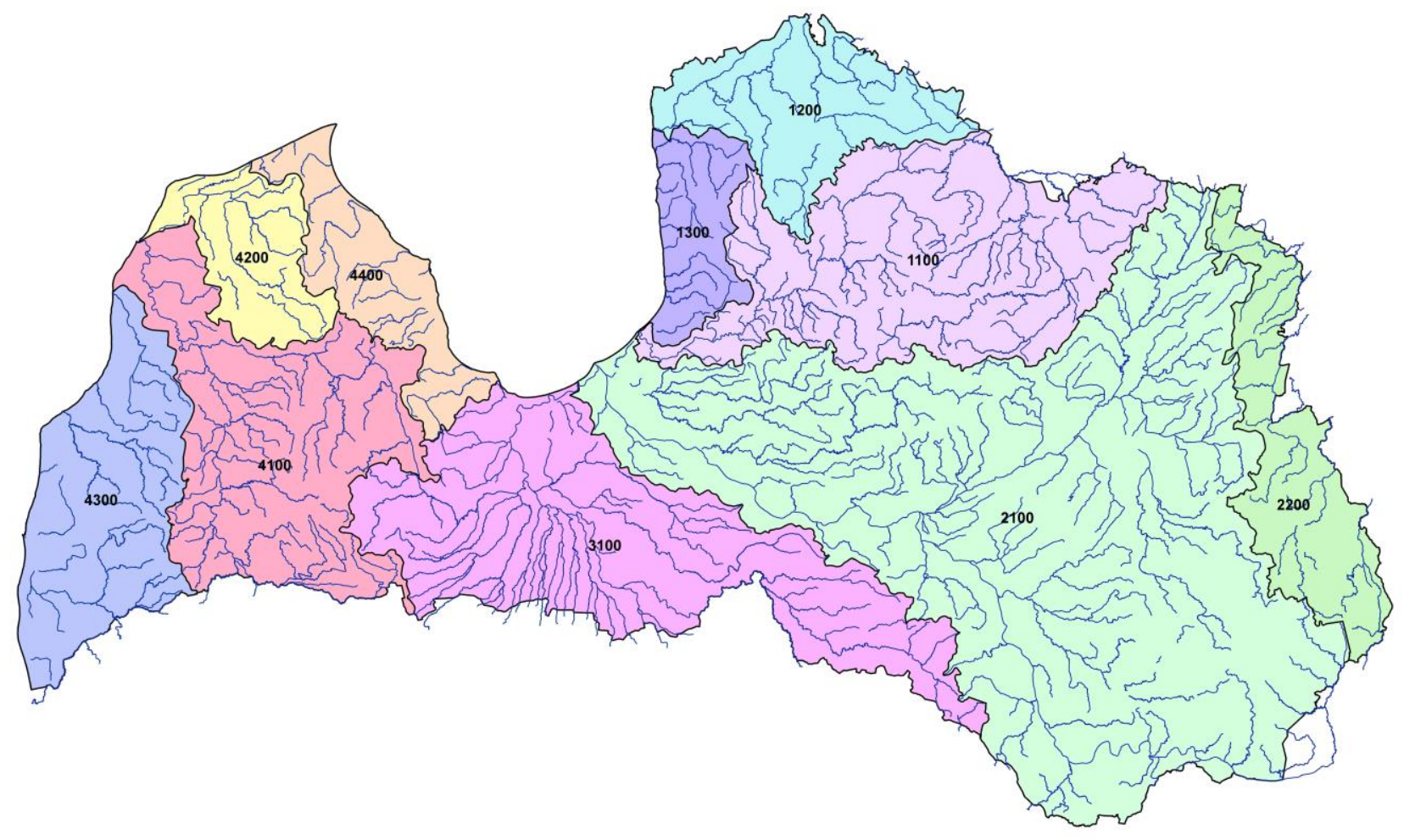

Fig. 3a. Ten river subbasins of Latvia.

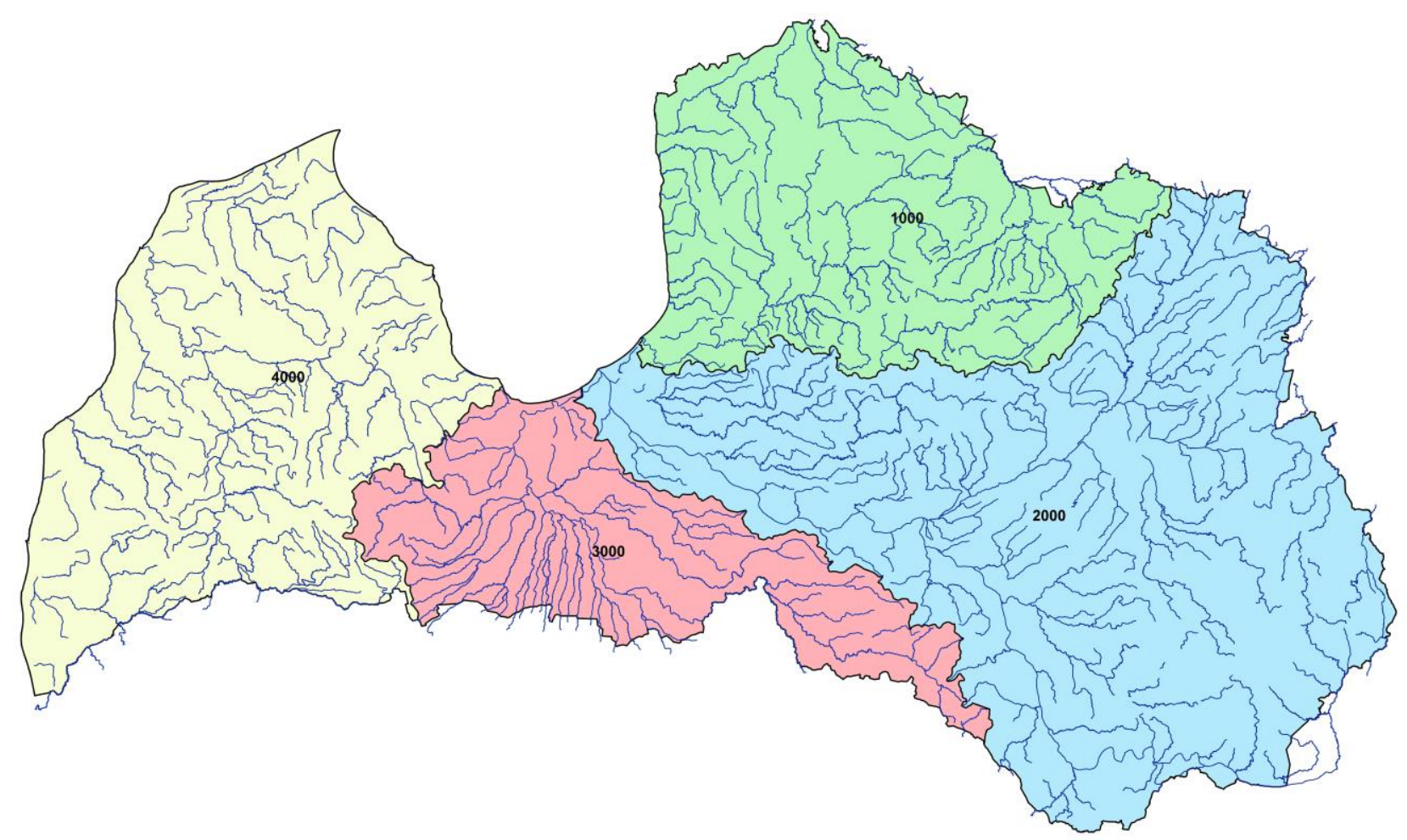

Fig. 4a. Four united river basins of Latvia. 


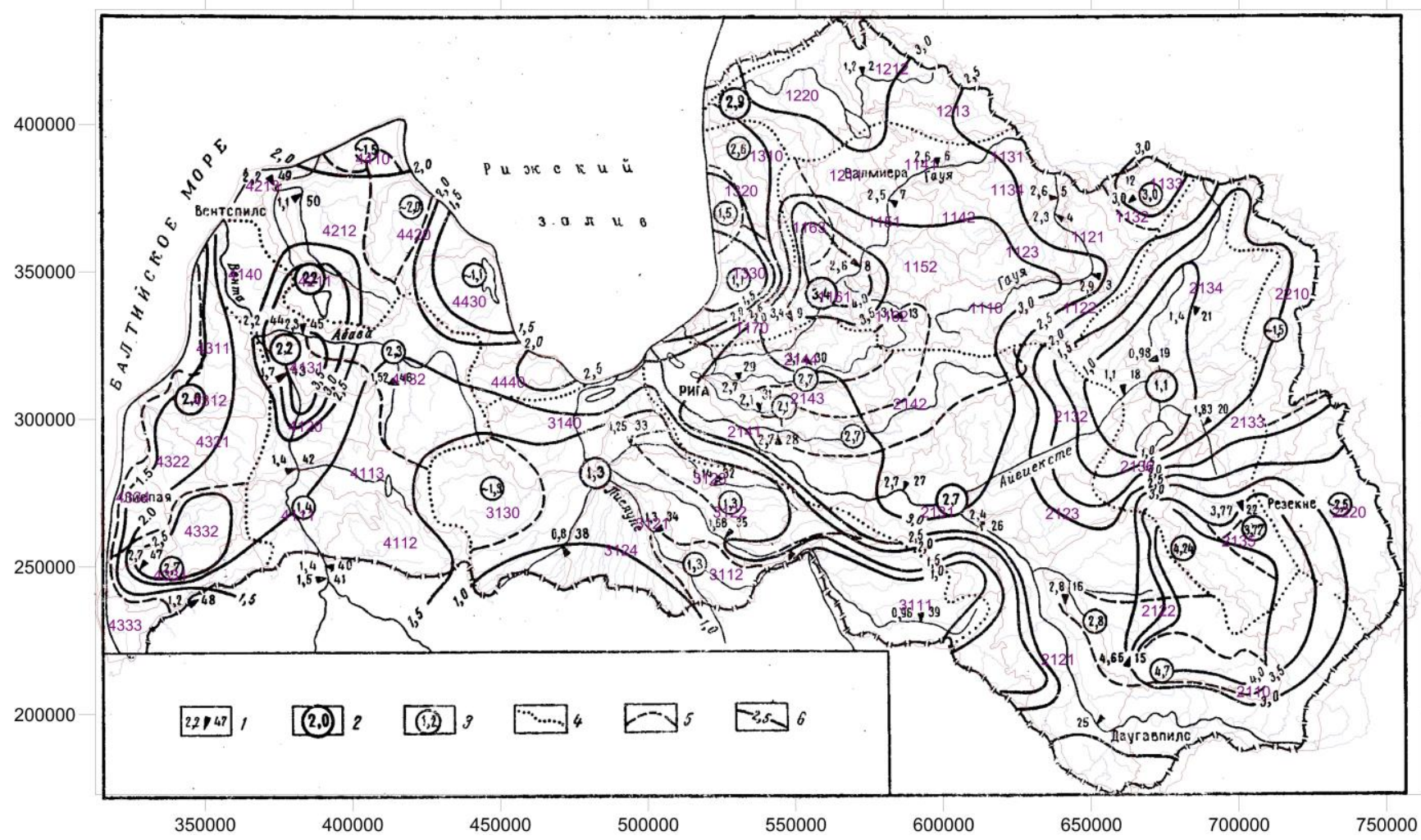

Fig. 5a. The map of drainage modules [12] projected on the map of primary basins.

TABLE IA

ESTIMATED RIVER BASE FLOWS FOR PRIMARY BASINS

\begin{tabular}{|c|c|c|c|c|c|c|c|}
\hline \multirow[t]{2}{*}{ No. } & \multirow[t]{2}{*}{ Name of the basin } & \multirow{2}{*}{$\begin{array}{l}\text { Primary } \\
\text { basin } \\
\text { index }\end{array}$} & \multirow{2}{*}{$\begin{array}{l}\text { Area, } \\
\mathrm{km}^{2}\end{array}$} & \multirow{2}{*}{$\begin{array}{c}\text { Drainage } \\
\text { module, } \\
\text { liter/sec km² }\end{array}$} & \multicolumn{3}{|c|}{ Flow, thous.m³/day } \\
\hline & & & & & Target & Simulated & Residual \\
\hline 1 & Gauja source-Velēna & 1110 & 719.2 & 2.70 & 168 & 166 & -2 \\
\hline 2 & Gauja Velēna-Gaujiena & 1121 & 481.3 & 2.80 & 116 & 118 & 2 \\
\hline 3 & Tirza & 1122 & 751.3 & 2.40 & 156 & 155 & -1 \\
\hline 4 & Vizla, Palsa & 1123 & 696.9 & 2.50 & 150 & 152 & 2 \\
\hline 5 & Gauja Gaujiena-Strenči & 1131 & 470.2 & 3.30 & 134 & 135 & 1 \\
\hline 6 & Melnupe & 1132 & 381.5 & 2.80 & 92 & 92 & 0 \\
\hline 7 & Vaidava & 1133 & 400.6 & 3.20 & 111 & 113 & 2 \\
\hline 8 & Vija & 1134 & 456.8 & 2.50 & 98 & 96 & -2 \\
\hline 9 & Gauja Strenči-Valmiera & 1141 & 359.2 & 1.90 & 59 & 58 & -1 \\
\hline 10 & Abuls & 1142 & 427.0 & 3.20 & 118 & 115 & -3 \\
\hline 11 & Gauja Valmiera-Cēsis & 1151 & 584.2 & 4.00 & 202 & 204 & 2 \\
\hline 12 & Rauna & 1152 & 409.0 & 3.30 & 117 & 116 & -1 \\
\hline 13 & Gauja Cēsis-Sigulda & 1161 & 480.5 & 9.30 & 386 & 380 & -6 \\
\hline 14 & Amata & 1162 & 388.7 & 5.70 & 191 & 190 & -1 \\
\hline 15 & Brasla & 1163 & 552.1 & 3.60 & 172 & 168 & -4 \\
\hline 16 & Gauja Sigulda-sea & 1170 & 370.1 & 5.40 & 172 & 173 & 1 \\
\hline 17 & Briede & 1211 & 542.1 & 3.00 & 140 & 143 & 3 \\
\hline 18 & Rūja & 1212 & 799.7 & 1.40 & 97 & 93 & -4 \\
\hline 19 & Seda & 1213 & 703.0 & 2.60 & 158 & 158 & 0 \\
\hline 20 & Salaca & 1220 & 1368.9 & 3.50 & 414 & 415 & -1 \\
\hline 21 & Svētupe & 1310 & 505.9 & 1.90 & 83 & 82 & -1 \\
\hline 22 & Vitrupe, Liepupe & 1320 & 422.1 & 2.10 & 76 & 76 & 0 \\
\hline 23 & Aǵe and other small rivers & 1330 & 733.7 & 1.10 & 70 & 71 & 1 \\
\hline 24 & Daugava border-Daugavpils & 2110 & 2459.9 & 2.60 & 552 & 549 & -3 \\
\hline 25 & Daugava Daugavpils-Jēkabpils & 2121 & 2210.0 & 2.70 & 516 & 523 & 7 \\
\hline 26 & Dubna & 2122 & 2753.4 & 2.50 & 595 & 589 & -6 \\
\hline
\end{tabular}




\begin{tabular}{|c|c|c|c|c|c|c|c|}
\hline 27 & Nereta & 2123 & 572.8 & 1.70 & 84 & 86 & 2 \\
\hline 28 & $\begin{array}{l}\text { Daugava Jēkabpils-Pḷaviṇu } \\
\text { HES }\end{array}$ & 2131 & 1517.1 & 2.30 & 301 & 301 & 0 \\
\hline 29 & Aiviekste & 2132 & 2946.3 & 2.30 & 585 & 582 & -3 \\
\hline 30 & Iča & 2133 & 1039.9 & 1.40 & 126 & 127 & 1 \\
\hline 31 & Pededze, Balupe & 2134 & 2457.5 & 1.90 & 403 & 407 & 4 \\
\hline 32 & Rēzekne, Malta & 2135 & 1968.3 & 2.50 & 425 & 416 & -9 \\
\hline 33 & Meirānu canal & 2136 & 706.1 & 1.20 & 73 & 73 & 0 \\
\hline 34 & Daugava Pḷavinu HES-sea & 2141 & 1693.8 & 1.60 & 234 & 234 & 0 \\
\hline 35 & Ogre & 2142 & 1681.4 & 2.50 & 363 & 360 & -3 \\
\hline 36 & Mazā Jugla & 2143 & 705.6 & 2.30 & 140 & 138 & -2 \\
\hline 37 & Lielā Jugla & 2144 & 943.9 & 3.10 & 253 & 249 & -4 \\
\hline 38 & Velikaja basin northern part & 2210 & 1200.3 & 1.50 & 155 & 149 & -6 \\
\hline 39 & Velikaja basin southern part & 2220 & 2207.3 & 2.00 & 381 & 331 & 10 \\
\hline 40 & Mēmele border-Viesìte & 3111 & 1896.8 & 1.20 & 196 & 203 & 7 \\
\hline 41 & Mēmele Viesīte-Bauska & 3112 & 489.5 & 2.70 & 114 & 113 & -1 \\
\hline 42 & Lielupe Bauska-Iecava & 3121 & 319.6 & 2.20 & 60 & 61 & 1 \\
\hline 43 & Iecava & 3122 & 1174.2 & 1.50 & 152 & 147 & -5 \\
\hline 44 & Misa & 3123 & 907.3 & 1.50 & 117 & 116 & -1 \\
\hline 45 & Rivers from Lithuanis & 3124 & 889.6 & 1.20 & 92 & 94 & 2 \\
\hline 46 & $\begin{array}{l}\text { Lielupe, Svēte Iecava and Svēte } \\
\text { months }\end{array}$ & 3130 & 1890.7 & 1.30 & 212 & 209 & -3 \\
\hline 47 & Lielupe Svētes mouth sea & 3140 & 1289.5 & 1.50 & 167 & 170 & 3 \\
\hline 48 & Venta border-Skrunda & 4111 & 917.4 & 2.80 & 222 & 222 & 0 \\
\hline 49 & Vadakste & 4112 & 785.6 & 1.80 & 122 & 122 & 0 \\
\hline 50 & Ciecere & 4113 & 534.7 & 1.70 & 78 & 79 & 1 \\
\hline 51 & Venta Skrunda-Kuldīga & 4120 & 942.6 & 2.60 & 211 & 208 & -3 \\
\hline 52 & Venta Kuldīga-Abava mouth & 4131 & 461.1 & 2.80 & 111 & 111 & 0 \\
\hline 53 & Abava & 4132 & 2058.2 & 2.10 & 373 & 379 & 6 \\
\hline 54 & Venta Abava mouth-sea & 4140 & 925.5 & 2.00 & 160 & 157 & -3 \\
\hline 55 & Rinda & 4211 & 672.2 & 1.70 & 99 & 100 & 1 \\
\hline 56 & Stende & 4212 & 1148.8 & 2.00 & 198 & 195 & -3 \\
\hline 57 & Irbe & 4213 & 270.8 & 2.10 & 49 & 51 & 2 \\
\hline 58 & Užava & 4311 & 776.1 & 1.50 & 100 & 99 & -1 \\
\hline 59 & Rīva & 4312 & 265.2 & 1.40 & 32 & 30 & -2 \\
\hline 60 & Saka & 4321 & 617.9 & 1.90 & 101 & 100 & -1 \\
\hline 61 & Durbe & 4322 & 479.0 & 1.70 & 70 & 69 & -1 \\
\hline 62 & Bārta & 4331 & 700.9 & 2.80 & 169 & 170 & 1 \\
\hline 63 & Vartaja & 4332 & 535.8 & 2.70 & 125 & 123 & -2 \\
\hline 64 & Sventaja & 4333 & 327.0 & 1.40 & 39 & 38 & -1 \\
\hline 65 & Liepāja lake small rivers & 4334 & 778.9 & 1.00 & 67 & 65 & -2 \\
\hline 66 & Pilsupe & 4410 & 417.5 & 1.40 & 50 & 50 & 0 \\
\hline 67 & Roja, Grīva & 4420 & 773.5 & 1.20 & 80 & 80 & 0 \\
\hline 68 & Engure lake rivers & 4430 & 870.1 & 1.40 & 105 & 106 & 1 \\
\hline 69 & Slocene & 4440 & 371.1 & 2.50 & 80 & 80 & 0 \\
\hline 70 & Latvia & 0 & 64554.7 & 2.22 & 12423 & 12388 & -35 \\
\hline
\end{tabular}

TABLE IIA

ESTIMATED RIVER BASE FLOWS FOR LAMO

\begin{tabular}{|l|c|c|c|c|}
\hline Name of the basin & Area, $\mathrm{km}^{2}$ & River flow, thous. $\mathrm{m}^{3} / \mathrm{day}$ & Drainage module, liter/sec $\mathrm{km}^{2}$ & Basin index \\
\hline Gauja united basin & 13004.0 & 3469 & 3.09 & 1000 \\
\hline Daugava united basin & 27063.6 & 5172 & 2.21 & 2000 \\
\hline Lielupe united basin & 8857.2 & 1113 & 1.45 & 3000 \\
\hline Venta united basin & 15629.9 & 2634 & 1.95 & 4000 \\
\hline Latva in total & 64554.7 & 12388 & 2.22 & 0 \\
\hline \multicolumn{7}{|c|}{ Base flows for subbasins of the Gauja united basin 1000 } \\
\hline Gauja basin & 7928.6 & 2431 & 3.50 & 1100 \\
\hline Salaca basin & 3413.7 & 809 & 2.74 & 1200 \\
\hline Basin of small rivers of Vidzeme coast & 1661.7 & 229 & 1.59 & 1300 \\
\hline In total & 13004.0 & 3469 & 3.09 & 1000 \\
\hline
\end{tabular}




\begin{tabular}{|c|c|c|c|c|}
\hline \multicolumn{4}{|c|}{ Base flows for subbasins of the Daugava united basin 2000} & \multirow[b]{2}{*}{2100} \\
\hline Daugava basin & 23656.0 & 4628 & 2.20 & \\
\hline Velikaja basin & 3407.6 & 544 & 1.85 & 2200 \\
\hline In total & 27063.6 & 5172 & 2.21 & 2000 \\
\hline \multicolumn{4}{|c|}{ Base flows for subbasins of the Venta united basin 4000} & \\
\hline Venta basin & 6625.1 & 1278 & 2.23 & 4100 \\
\hline Irbe basin & 2091.8 & 346 & 1.91 & 4200 \\
\hline $\begin{array}{l}\text { Basin of small rivers for western } \\
\text { Kurzeme coast }\end{array}$ & 4480.8 & 694 & 1.79 & 4300 \\
\hline $\begin{array}{l}\text { Basin of small rivers for eastern } \\
\text { Kurzeme coast }\end{array}$ & 2432.2 & 316 & 1.50 & 4400 \\
\hline In total & 15629.9 & 2634 & 1.95 & 4000 \\
\hline
\end{tabular}

TABLE IIIA

BASE FLOWS FOR SEGMENTS OF THE GAUJA RIVER 1100

\begin{tabular}{|c|c|c|c|c|c|c|c|}
\hline \multirow[t]{2}{*}{ No. } & \multirow{2}{*}{$\begin{array}{l}\text { Index of } \\
\text { segment }\end{array}$} & \multicolumn{2}{|c|}{ Area, $\mathrm{km}^{2}$} & \multicolumn{2}{|c|}{ River flow, thous.m³/day } & \multicolumn{2}{|c|}{ Drainage module, liter/sec $\mathrm{km}^{2}$} \\
\hline & & Segment & River & Segment & River & Segment & River \\
\hline 1 & 1110 & 719.2 & 719.2 & 160 & 160 & 2.67 & 2.67 \\
\hline 2 & 1120 & 1929.5 & 2648.7 & 425 & 591 & 2.55 & 2.59 \\
\hline 3 & 1130 & 1709.1 & 4357.8 & 436 & 1027 & 2.97 & 2.72 \\
\hline 4 & 1140 & 786.2 & 5144.0 & 173 & 1200 & 2.57 & 2.70 \\
\hline 5 & 1150 & 993.2 & 6137.2 & 320 & 1520 & 3.74 & 2.88 \\
\hline 6 & 1160 & 1421.3 & 7558.5 & 738 & 2258 & 6.01 & 3.46 \\
\hline 7 & 1170 & 370.1 & 7928.6 & 173 & 2431 & 5.41 & 3.55 \\
\hline In total & 1100 & & 7928.6 & & 2431 & & 3.55 \\
\hline
\end{tabular}

BASE FLOWS FOR SEGMENTS OF THE DAUGAVA RIVER 2100

\begin{tabular}{|l|l|l|l|l|l|l|l|}
\hline \multirow{2}{*}{ No. } & \multirow{2}{*}{$\begin{array}{l}\text { Index of } \\
\text { segment }\end{array}$} & \multicolumn{2}{|c|}{ Area, $\mathrm{km}^{2}$} & \multicolumn{2}{c|}{ River flow, thous.m $\mathrm{m}^{3} / \mathrm{day}$} & Drainage module, liter/sec $\mathrm{km}{ }^{2}$ \\
\cline { 3 - 8 } & Segment & River & Segment & River & Segment \\
\hline 1 & 2110 & 2459.9 & 2459.9 & 549 & 549 & 2.58 & 2.58 \\
\hline 2 & 2120 & 5536.2 & 7936.1 & 1192 & 1741 & 2.50 & 2.55 \\
\hline 3 & 2130 & 10635.2 & 18631.3 & 1906 & 3647 & 2.09 & 2.27 \\
\hline 4 & 2140 & 5024.7 & 23656.0 & 981 & 4628 & 2.26 \\
\hline In total & 2100 & & 23656.0 & & 4628 & & 2.26 \\
\hline
\end{tabular}

BASE FLOWS FOR SEGMENTS OF THE LIELUPE RIVER 3100

\begin{tabular}{|c|c|c|c|c|c|c|c|}
\hline \multirow{2}{*}{ No. } & \multirow{2}{*}{$\begin{array}{l}\text { Index of } \\
\text { segment }\end{array}$} & \multicolumn{2}{|l|}{ Area, $\mathrm{km}^{2}$} & \multicolumn{2}{|c|}{ River flow, thous.m ${ }^{3} /$ day } & \multicolumn{2}{|c|}{ Drainage module, liter/sec $\mathrm{km}^{2}$} \\
\hline & & Segment & River & Segment & River & Segment & River \\
\hline 1 & 3110 & 2386.3 & 2386.3 & 316 & 316 & 1.53 & 1.53 \\
\hline 2 & 3120 & 3290.7 & 5677.0 & 418 & 734 & 1.47 & 1.50 \\
\hline 3 & 3130 & 1890.7 & 7567.7 & 209 & 943 & 1.28 & 1.44 \\
\hline 4 & 3140 & 1289.5 & 8857.2 & 170 & 1113 & 1.32 & 1.45 \\
\hline In total & 3100 & & 8857.2 & & 1113 & & 1.45 \\
\hline
\end{tabular}

BASE FLOWS FOR SEGMENTS OF THE VENTA RIVER 4100

\begin{tabular}{|l|l|l|l|l|l|l|l|}
\hline \multirow{2}{*}{ No. } & \multirow{2}{*}{$\begin{array}{l}\text { Index of } \\
\text { segment }\end{array}$} & Area $\mathrm{km}^{2}$ & \multicolumn{2}{l|}{ River flow, thous. ${ }^{3} / \mathrm{day}$} & \multicolumn{2}{l|}{ Drainage module, liter/sec $\mathrm{km}^{2}$} \\
\cline { 3 - 8 } & Segment & River & Segment & River & Segment \\
\hline 1 & 4110 & 2237.7 & 2237.7 & 423 & 423 & 2.19 & 2.19 \\
\hline 2 & 4120 & 942.6 & 3180.3 & 208 & 631 & 2.55 & 2.30 \\
\hline 3 & 4130 & 2519.3 & 5699.6 & 490 & 1121 & 2.25 & 2.28 \\
\hline 4 & 4140 & 925.5 & 6625.1 & 157 & 1278 & 1278 & \\
\hline In total & 4100 & & 6625.1 & & & 2.23 \\
\hline
\end{tabular}




\section{REFERENCES}

[1] Water Framework Directive. 2000. (2000/60/EC of the European Parliament and of the Council). Official Journal of the European Communities, L327, 22.12.2000.

[2] Environmental Simulations, Inc., Groundwater Vistas. Version 6, Guide to using, 2011.

[3] A. Spalvins, J. Slangens, I. Lace, K. Krauklis, and O. Aleksans, "Efficient Methods Used to Create Hydrogeological Model of Latvia," In International Review on Modelling and Simulations (I.RE.MO.S), Praise Worthy Prize, vol. 6, no. 5, Okt. 2013, pp. 1718-1726.

[4] A. Spalvins, J. Slangens, I. Lace, O. Aleksans, K. Krauklis, "Improvement of hydrogeological models: a case study," International Review on Modelling and Simulations (I.RE.MO.S.), Praise Worthy Prize, Naples, Italy, vol. 8, no. 2, April 2015, pp. 266-276

[5] A. Spalvins, O. Aleksans, I. Lace, "Improving of transmissivity maps for hydrogeological model of Latvia," in $15^{\text {th }}$ international multidisciplinary scientific geo conference (SGEM 2015), June 18-24, 2015, Albena, Bulgaria, Conference Proceedings, 2015, vol. 1, pp. 667-684

[6] A. Spalvins, I. Lace, K. Krauklis, "Improved methods for obtaining permeability maps of aquifers for hydrogeological model of Latvia," Scientific Journal of Riga Technical University, Boundary Field Problems and Computer Simulation, RTU Press, Riga, 2015. http://dx.doi.org/10.7250/bfpcs.2015.006

[7] K. Krauklis, A.Spalvins, J. Slangens, "Hidrogeological model of Latvia LAMO4 as a tool for investigating processes of nature. Sources of groundwater inflow for Iecava river," Scientific Journal of Riga Technical University, Boundary Field Problems and Computer Simulation, RTU Press, Riga, 2015. http://dx.doi.org/10.7250/bfpcs.2015.007

[8] G. Strang, Linear algebra and its applications. Academic Press Inc., New York, 1976, p. 373.

9] A.W. Harbaugh, MODFLOW-2005, U.S. Geological Survey Modular Ground-Water Model: the ground-water flow process, chap 16, book 6, US Geological Survey Techniques and Methods 6-A16, USGS, Reston, VA

[10] Pollok D. W. User's Guide for MODPATH/MODPATH-Plot, Version3. A particle tracking post-processing package for MODFLOW, the US Geological Survey finite-difference groundwater flow model, U.S Geological survey, September 1994

[11] R. Mokrik, V. Juodkazis, A. Stuopis, and J. Mazeika, "Isotope geochemistry and modelling of the multi-aquifer system in the eastern part of Lithuania," Hydrogeology journal, vol. 22, 2014, pp. 925-941. http://dx.doi.org/10.1007/s10040-014-1120-6

[12] Dzenis-Litovsky A. I., editor, Hydrogeology of USSR, Latvian SSR, Volume XXXI, part1, Nedra, Moskow 1967, p. 200 (in Russian).

[13] I. Dzilna, Resources, composition and dynamics of groundwater for the middle part of the Baltic area. (Zinatne, Riga, 1970, p. 197, (in Russian).

[14] P.A. Domenico, and F.W. Schwartz. Physical and Chemical Hydrogeology, John Wiley and sons, Inc. -2 end ed. New York, p. 506, 1998.

[15] De Barry, Paul A., Watersheds: processes assessment and management. Willey and Sons Inc. Hoboken, New Jersey, 2004, p. 700.

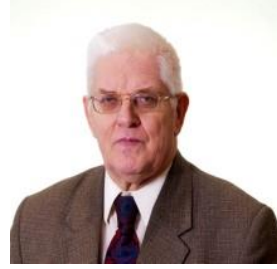

Aivars Spalvins was born in Latvia. In 1963, he graduated from the Riga Polytechnical Institute (since 1990 - Riga Technical University) as a Computer Engineer. A. Spalvins is the Head of the Environment Modelling Centre of RTU. His research interests include computer modeling of groundwater flows and migration of contaminants. E-mail: aivars.spalvins@rtu.lv

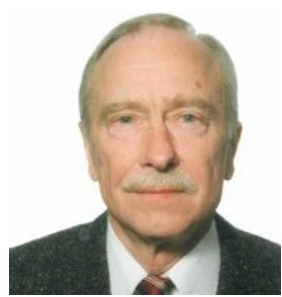

Janis Slangens was born in Latvia. In 1969, he graduated from the Riga Polytechnical Institute (since 1990 - Riga Technical University) as a Computer Engineer. J. Slangens is a senior researcher at the Environment Modelling Centre of RTU. His research interests include computer modeling of groundwater flows

E-mail: janis.slangens@rtu.lv

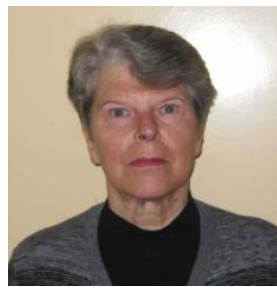

Inta Lace was born in Latvia. In 1971, she graduated from the Riga Polytechnical Institute (since 1990 - Riga Technical University) as a Computer Engineer. In 1995, I. Lace received the Master's degree in Applied Computer Science. Since 1991, she is a researcher at the Environment Modelling Centre of the Faculty of Computer Science and Information Technology, RTU.

E-mail: inta.lace@yahoo.com

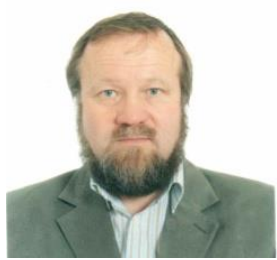

Olgerts Aleksans was born in Latvia. In 1979, he graduated from Vilnius State University as a Hydrogeologist \& Engineering Geologist. In 2011, O. Aleksans received the Doctor's degree in Geology. Since 2011, he is a researcher at the Environment Modelling Centre of RTU.

E-mail: oal@dge.lv

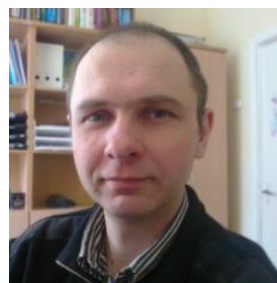

Kaspars Krauklis received the Master's degree in Computer Systems from the Riga Technical University in 2007 and the Certificate in Teaching of Engineering Sciences from the Institute of Humanities of RTU in 2005. He is a researcher at the Environment Modelling Centre of RTU.

E-mail: Kaspars.Krauklis@gmail.com

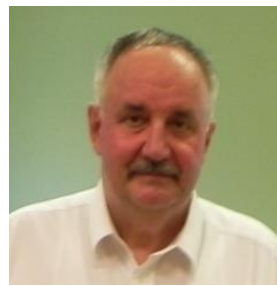

Viesturs Skibelis was born in Germany in 1945. In 1967, he graduated from the Riga Polytechnical Institute (since 1990 - Riga Technical University) as a Computer Engineer. In 2001, he received the Master's degree in Applied Computer Science. He is a researcher at the Environment Modelling Centre of RTU

E-mail: Viesturs.Skibelis@cs.rtu.lv

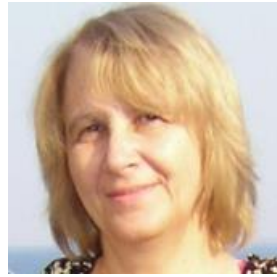

Irina Eglite received the Master's degree in Mathematics from the University of Latvia and the Master's degree in Applied Computer Science from the Riga Technical University. She is a $\mathrm{PhD}$ student at RTU, a researcher at the Environment Modelling Centre and a lecturer at the Department of Engineering Mathematics, RTU. E-mail: Irina.Eglite@rtu.lv 